\title{
Manajemen Risiko Operasional Pada PT Bank Pembiayaan Rakyat Syariah (BPRS) Jabal Nur Tebuireng di Surabaya
}

\author{
Wienanda Rizka Sukma Jelita \& Atina Shofawati \\ Program Studi Ekonomi Syariah, \\ Fakultas Ekonomi dan Bisnis, Universitas Airlangga \\ Email: wee.wienanda@gmail.com
}

\begin{abstract}
This study present to determine the management analysis of BPRS. This study was conducted at management that is different from the phenomenon that occurs in the object of research, namely PT BPRS Jabal Nur Tebuireng. This study uses qualitative methods with a case study approach. The way to manage the data is done by a focused openended method. The analysis technique used is matchmaking of patterns by comparing empirical patterns with predicted patterns. PT BPRS Jabal Nur Tebuireng has carried out operational management in accordance with ISO 31000 (2009). Possible conditions, but at the time of BPRS analysis Jabal Nur did not make a list of risks in which there was a Composite Risk Index (CRI) and made a matrix. In the evaluation phase, it was found that BPRS Jabal Nur Tebuireng were people involved in internal processes and fraud. So far BPRS Jabal Nur Tebuireng has been handling various operations.
\end{abstract}

Keywords: Risk Management, Operational Risk, Risk Procces. 


\begin{abstract}
ABSTRAK
Penelitian ini bertujuan untuk menganalisis hubungan pembiayaan bank syariah untuk meningkatkan jumlah wisatawan halal dan pertumbuhan Pendapatan Asli Daerah (PAD) Periode 2015-2016 pada 33 provinsi di Indonesia. Menggunakan metode penelitian granger kausalitas dan panel regresi berganda dengan analisis data Minitab. Model ini menganalisis pengaruh kontribusi pembiayaan bank syariah terhadap jumlah wisatawan halal dan Pendapatan Asli Daerah (PAD). Jumlah Pembiayaan bank syariah di sektor pariwisata seperti restoran dan penginapan telah berkontribusi meningkatkan jumlah wisatawan halal dan pertumbuhan pendapatan asli daerah (PAD). Hasil studi ini dapat digunakan untuk industri perbankan syariah sebagai upaya mendukung modal pembiayaan untuk industri halal. Dalam penelitian sebelumnya hanya dianalisis tentang potensi wisata halal, serta potensi industri pariwisata secara umum untuk pendapatan lokal yang dihasilkan. Namun, penelitian ini membahas kontribusi pembiayaan bank syariah terhadap jumlah halal pariwisata dan peningkatan Pendapatan Asli Daerah (PAD) yang didapat.
\end{abstract}

Kata Kunci: Pembiayaan, Bank Syariah, Pariwisata Halal.

\title{
1. Introduction
}

Bank Pembiayaan Syariah adalah Bank Syariah yang dalam kegiatannya tidak memberikan jasa dalam lalu lintas pembayaran. Kegiatan usaha Bank Pembiayaan Rakyat Syariah meliputi lima aspek penting, yaitu: pertama, menghimpun dana dari masyarakat dalam bentuk simpanan dan investasi. Kedua, menyalurkan dana kepada masyarakat dalam bentuk pembiayaan bagi hasil, pembiayaan murabahah, salam, atau istishna', pembiayaan berdasarkan qardh, dan pembiayaan penyewaan barang bergerak atau tidak bergerak. Ketiga, menempatkan dana pada Bank Syariah lain dalam bentuk titipan atau investasi. Keempat, memindahkan uang, baik untuk kepentingan sendiri maupun untuk kepentingan Nasabah. Kelima, menyediakan produk atau melakukan kegiatan usaha Bank Syariah lainnya yang sesuai dengan Prinsip Syariah berdasarkan persetujuan Bank Indonesia (sekarang OJK) (www.ojk.go.id).

Berikut adalah tabel pertumbuhan jumlah bank Pembiayaan Syariah di Indonesia:

Tabel 1.1

Pertumbuhan Jumlah Bank Pembiayaan Syariah di Indonesia

\begin{tabular}{cccccc}
\hline Tahun & $\mathbf{2 0 1 3}$ & $\mathbf{2 0 1 4}$ & $\mathbf{2 0 1 5}$ & $\mathbf{2 0 1 6}$ & $\mathbf{2 0 1 7}$ \\
\hline Jumlah & 163 & 163 & 163 & 166 & 167 \\
\hline
\end{tabular}




\section{BPRS}

Sumber: Statistik Perbankan Syariah (SPS) Mei, 2018

Dalam praktik, BPR syariah mengalami berbagai kendala, kendala tersebut diantaranya adalah (Sudarsono, 2007: 93): pertama, BPR syariah kurang dikenal masyarakat sebagai BPR yang berprinsipkan syariah, bahkan beberapa pihak menganggap BPR syariah sama dengan BPR konvensional. Oleh karena itu, BPR syariah perlu menegaskan dan meneguhkan identitasnya sebagai BPR yang menggunakan prinsip syariah. Kedua, upaya untuk meningkatkan profesionalitas kadang terhadalang rendahnya sumber daya yang dimiliki oleh BPR syariah sehingga proses BPR syariah dalam melakukan aktivitasnya cenderung lambat dan respon terhadap permasalahan ekonomi rendah. Maka upaya untuk meningkatkan SDM perlu diarahkan di semua posisi, baik di posisi pemegang kebijakan ataupun berposisi di lapangan. Ketiga, kurang adanya koordinasi di antara BPR syariah, demikian juga dengan bank syariah dan BMT, sebagai lembaga keuangan yang mempunyai syiar Islam tentunya langkah koordinasi dalam rangka mendapatkan strategi yang terpadu dapat dilakukan guna mengangkat ekonomi masyarakat. Oleh karena itu dibutuhkan framework yang bisa dijadikan acuan di antara lembaga keuangan di tingkat kabupaten, kecamatan, desa ataupun pasar dalam melangsungkan aktivitasnya tanpa mengesampingkan keberadaan lembaga keuangan yang lain. Keempat, sebagai lembaga keuangan yang meliki konsep Islam tentunya juga bertanggung jawab terhadap nilai-nilai keislaman masyarakat yang ada disekitar BPR syariah tersebut. Aktivitas BPR syariah di bidang keuangan sering kali tidak memberikan sedikit waktu untuk melakukan aktivitas yang berhubungan dengan syiar Islam, artinya aktivitas keuangan BPR syariah perlu memprakarsai terbentuknya majelis-majelis taklim dan semacamnya.

Masa depan perbankan Islam akan sangat ditentukan oleh kemampuan manajemen perbankan Islam dalam menghadapi berbagai perubahan pesat, seperti globalisasi, pesatnya informasi dan teknologi serta inovasi keuangan. Kondisi ini berpotensi meningkatkan deraan risiko terhadap perbankan Islam di mana semua risiko ini mutlak harus dikelola (Wahyudi, dkk, 2013: 2). Ibarat satu koin, imbal hasil dan risiko akan senantiasa melekat pada suatu bisnis. Dalam suatu kaidah fikih disebutkan "al ghunmu bil ghurmi" dan "al kharaju bidh dhamani" atau dikenal dalam istilah keuangan modern dengan "risk-return trade-off". Karenanya, penerapan manajemen risiko yang andal sama pentingnya dengan penetapan berbagai strategi bisnis untuk optimalisasi imbal hasil (Wahyudi, dkk, 2013: xi).

Oleh karena itu, manajemen risiko yang baik sangat penting bagi kelangsungan usaha bank syariah maupun BPR Syariah. Islam juga mengajarkan bahwa setiap manusia tidak ada satupun yang mengetahui apa yang akan terjadi dan apa yang akan diusahakan di masa yang akan datang (QS. Luqman[31]: 34). 
Untuk terciptanya manajemen risiko yang baik, pihak perbankan syariah perlu untuk mengetahui risiko apa saja yang terjadi pada perbankan. Terdapat beberapa jenis risiko yang dapat terjadi pada perbankan syariah maupun konvensional, salah satunya adalah risiko operasional. Risiko operasional adalah risiko kerugian yang diakibatkan oleh proses internal yang kurang memadai, kegagalan proses internal, kesalahan manusia, kegagalan sistem, dan/ atau adanya kejadian-kejadian eksternal yang mempengaruhi operasional Bank (Bank Indonesia, 2011). Bank syariah dianggap lebih rentan terhadap risiko operasional yang terkait dengan kegagalan pengendalian, prosedur, sistem teknologi informasi, dan model analitis (Greuning,dkk, 2011: 166).

Risiko operasional dianggap tinggi dalam daftar risiko-risiko yang dihadapi oleh bank syariah. Survei yang dilakukan oleh Khan dan Ahmed (2001) menunjukkan bahwa manajer bank syariah menganggap risiko operasional sebagai risiko yang paling penting setelah risiko markup. Survey tersebut menemukan bahwa risiko operasional lebih rendah dalam perjanjian pendapatantetap murobahah (penjualan biaya-plus) dan ijaroh (leasing) serta lebih tinggi dalam perjanjian penjualan tangguhan atau salaam (pertanian) dan istisna (manufaktur). Peringkat yang relatif lebih tinggi dari instrumen ini menunjukan bahwa bank menganggap perjanjian ini lebih rumit dan sulit untuk dilaksanakan (Greuning,dkk, 2011: 167). Penelitian ini bertujuan untuk melakukan analisis secara mendalam terkait manajemen risiko operasional pada PT BPRS Jabal Nur Tebuireng di Surabaya.

\section{Landasan Teori}

\subsection{Bank Pembiayaan Rakyat Syariah}

Bank Perkreditan Rakyat (BPR) menurut Undang-Undang (UU) Perbankan No. 7 tahun 1992, adalah lembaga keuangan bank yang menerima simpanan hanya dalam bentuk deposito berjangka tabungan dan/ atau bentuk lainnya yang dipersamakan dengan itu dan menyalurkan dana sebagai usaha BPR. Sedangkan pada UU Perbankan No. 10 tahun 1998, disebutkan bahwa BPR adalah lembaga keuangan bank yang melaksanakan kegiatan usahanya secara konvensional atau berdasarkan prinsip syariah (Sudarsono, 2007: 83).

Pelaksanaan BPR yang melakukan kegiatan usaha berdasarkan prinsip syariah selanjutnya diatur menurut Surat Keputusan Direktur Bank Indonesia No. 32/36/KEP/DIR/1999 tanggal 12 Mei 19999 tentang Bank Pengkreditan Rakyat Syariah. Dalam hal ini, secara teknis BPR syariah bisa diartikan sebagai lembaga keuangan sebagaimana BPR konvensional, yang operasinya menggunakan prinsip-prinsip syariah (Sudarsono, 2007:83).

\subsection{Risiko Operasional}

Risiko operasional didefinisikan dengan risiko kerugian kerugian sebagai akibat dari ketidakcukupan atau kegagalan proses internal, yang terkait dengan 
manusia dan sistem, atau risiko eksternal. Risiko operasional juga meliputi risiko kegagalan teknologi, sistem dan model analisis. Risiko operasional lebih signifikan bagi bank syariah karena fitur perjanjian mereka yang khusus dan lingkungan hukum umum. Aspek khusus dari perbankan syariah dapat meningkatkan risiko operasional dari bank syariah (Greuning, dkk, 2011: 165166), diantaranya adalah, (a) risiko pembatalan dalam murobahah tidak terikat (kemitraan) dan perjanjian istisnah (manufaktur). (b) kegagalan sistem pengendalian internal untuk mendeteksi dan mengelola potensi permasalahan dalam proses operasional dan fungsi back-office juga berbagai macam risikorisiko teknis. (c) potensi kesulitan dalam menegakkan perjanjian Islam dalam lingkungan hukum yang lebih luas. (d) pemeliharaan dan pengelolaan persediaan komoditas dalam pasar yang tidak likuid. (e) kegagalan untuk mematuhi persyaratan syariat. (f) potensi biaya dan risiko dalam memantau perjanjian berjenis ekuitas dan risiko terkait.

\subsection{Proses Manajemen Risiko}

Menurut Wahyudi, dkk (20013: 59) Proses manajemen risiko merupakan tindakan dari seluruh entitas terkait di dalam perusahaan yang didalamnya terdapat berbagai tahapan yang saling berkaitan dan berulang untuk saling melengkapi dan menyempurnakan. Jika pada manajemen risiko klasik pengelolaan risiko terpisah dari aktivitas bisnis perbankan, maka pada manajemen risiko modern pengelolaan risiko tidak bisa terlepas dari kegiatan bisnis perbankan. Pada bank islam, proses manajemen risiko berjalan beriringan dengan proses bank islam itu sendiri dan menyatu dengan seluruh aktivitas bisnis yang dilakukan oleh bank islam. Tujuan utama dari manajemen risiko sendiri adalah untuk memastikan bahwa seluruh kebijakan risiko dan bisnis bisa diimplementaikan secara konsisten.

Pada tahap penentuan konteks, semua hal terkait dengan rincian manajemen risiko diperjelas dan didefinisikan. Kemuadian setelah tahapan penentuan konteks, secara berurutan dilakukan tahapan identifikasi risiko, analisis risiko, evaluasi risiko, perlakuan risiko, dan monitor dan review. Semua tahapan tersebut dikomunikasikan dan dikonsultasikan dengan baik. Gambar berikut merupakan alur proses manajemen risiko (ISO 31000, 2009 dalam Wahyudi, dkk, 2013:61): 
Gambar 1.1

Proses Manajemen Risiko

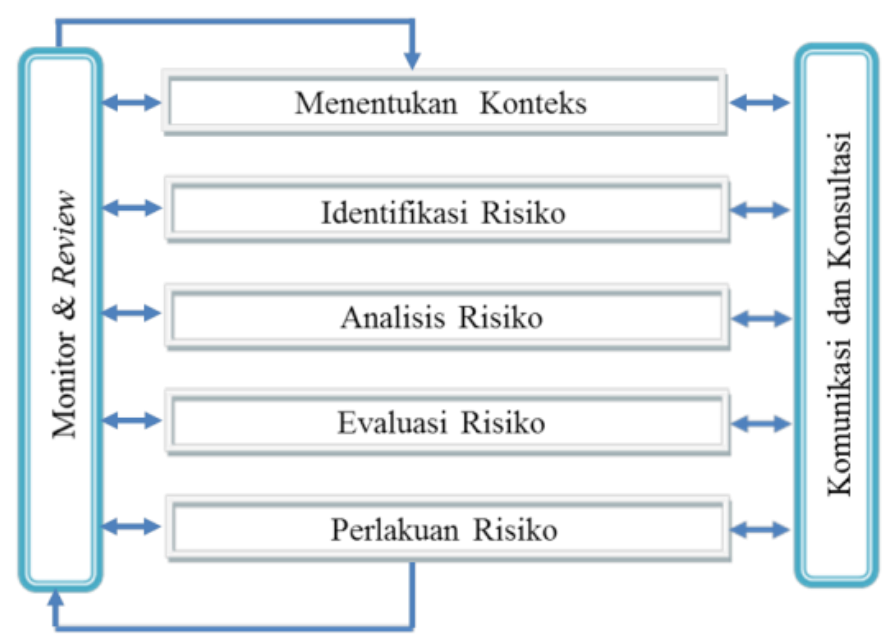

Sumber: Wahyudi, dkk (2013: 61)

Proses manajemen pada gambar 1.1 diatas dijelaskan sebagai berikut:

1) Penentuan konteks

Tahapan awal yang dilakukan dalam proses manajemen risiko adalah menentukan batasan atau parameter internal dan eksternal yang harus dilakukan sesuai dengan kebutuhan dan pada setiap tahapan proses manajemen risiko (ISO 31000, 2009). Wahyudi, dkk (2013: 62) menjelaskan hal-hal yang harus dilakukan dalam tahapan penentuan konteks, yaitu sebagai berikut:

a) Identifikasi risiko yang menjadi area asal kepentingan.

b) Perencanaan proses manajemen risiko selanjutnya.

c) Penetapan lingkup sosial manajemen risiko, identitas dan tujuan kepentingan.

d) Kriteria dan dasar untuk mengevaluasi risiko.

e) Mendefinisikan kerangka kerja untuk aktivitas dan agenda identifikasi.

f) Mengembangkan kriteria analisis risiko-risiko yang terlibat dalam proses.

g) Mitigasi atau solusi risiko dengan menggunakan teknologi, SDM, dan sumber daya yang ada.

Tujuan dari dilakukannya tahapan penentuan konteks adalah sebagai berikut (Wahyudi, dkk, 2013:62):

a) Memperoleh gambaran menyeluruh atas parameter dasar, ruang lingkup, dan kerangka kerja manajemen risiko.

b) Mengidentifikasi lingkungan penerapan manajemen risiko.

c) Mengetahui dan menetapkan para pemangku kepentingan utama. 
d) Menetapkan kriteria untuk menganalisis dan mengevaluasi risiko.

\section{2) Identifikasi Risiko}

Setelah tahapan pentuan konteks dilakukan, mengidentifikasi risiko merupakan tahapan yang harus dilakukan selanjutnya. Wahyudi, dkk (2013: 66) menjelaskan bahwa identifikasi risiko merupakan sebuah proses untuk menentukan risiko apa yang terjadi, mengapa dan bagaimana risiko terjadi.

Terdapat beberapa tahapan dalam identifikasi risiko, yaitu sebagai berikut (Wahyudi, 2013:66):

a) Menyusun daftar risiko secara komprehensif. Risiko yang mungkin terjadi disusun berdasarkan dampak pada setiap elemen kegiatan.

b) Menganalisis karakteristik risiko yang melekat pada bank islam, risiko yang melekat pada produk maupun kegiatan usaha bank.

c) Menggambarkan proses terjadinya risiko dengan menganalisis fakto-faktor apa yang menjadi penyebab timbulnya risiko dan menentukan besarnya probabilitas sebuah risiko akan terjadi.

d) Membuat daftar sumber terjadinya risiko untuk masing-masing risiko.

e) Menentukan pendekatan atau instrumen yang tepat untuk identifikasi risiko, misalnya berdasarkan pengalaman, pencatatan atas risiko yang pernah terjadi, dan sebagainya.

Sedangkan menurut (Idroes, 2008: 8) tahapan dalam identifikasi risiko yaitu sebagai berikut:

a) Menetapkan kerangka kerja untuk implementasi strategi secara keseluruhan.

b) Menentukan definisi kerugian.

c) Menyusun dan melakukan implementasi mekanisme pengumpulan data.

d) Membuat pemetaan kerugian ke dalam kategori risiko yang dapat diterima dan tidak dapat diterima.

\section{3) Analisis Risiko}

Setelah melakukan identifikasi, langkah selanjutnya adalah analisis risiko, analisis risiko adalah upaya memahami risiko yang sudah diidentifikasi secara lebih mendalam yang hasilnya akan menjadi masukan bagi evaluasi risiko (ISO 31000, 2009). Wahyudi, dkk, (2013: 68-70) menjelaskan proses manajemen risiko pada tahapan analisis risiko terdapat tahapan di mana bank islam perlu menyusun risk register yang didalamnya terdapat perhitungan composite risk index (CRI) dan menyusun matriks risiko. CRI adalah metodologi penilaian risiko dengan mengalikan dampak kejadian risiko dengan probabilitas kejadian (Wahyudi, dkk, 2013: 64). Matriks risiko digunakan untuk mengidentifikasi risiko, menghitung probabilitas keterjadian dan besarnya pengaruh kejadian tersebut, kemudian 
memeringkat risiko berdasarkan preferensi risiko yang dipilih oleh manajemen bank. Dalam penyusunan matriks risiko, bank harus merinci berbagai macam kategori risiko yang ada pada aktivitas bank dan kemudian merinci kejadian apa saja yang ada pada setiap kategori risiko tersebut. Kemudian dilakukan identifikasi tingkat keparahan dan kemungkinan terjadinya kejadian yang menimbulkan risiko, dan ditampilkan dalam satuan uang. Keduanya diberi skala 1-5, dimana untuk tingkat keparahan dan kemungkinan terjadinya kejadian rendah, diberi nilai 1 dan sebaliknya jika tingkat kemungkinan terjadinya kejadian tinggi, diberi nilai 5. Dengan demikian perkalian dari dua komponen tersebut akan menghasilkan interval 1-25, dimana nilai 1 untuk menandakan tingkat keparahan dan kemungkinan terjadinya kejadian rendah, dan nilai 25 menandakan tingkat keparahan dan kemungkinan terjadinya kejadian tinggi.

4) Evaluasi Risiko

Wahyudi (2013: 75) menyatakan bahwa evaluasi risiko merupakan proses yang sangat penting karena akan menentukan lagkah dan tindakan yang dapat diambil manajemen untuk mengolah risiko tersebut. Tujuan dilakukannya evaluasi dan review risiko adalah untuk membantu proses pengambilan keputusan, berdasarkan analisis yang didapatkan dari analisis risiko, untuk melakukan berbagai kebijakan terkait perlakuan terhadap risiko da prioritas pengelolaan risiko yang harus dilakukan.

5) Perlakuan Risiko

Menurut Pradipta (2016: 55) tahap ini adalah tahap penanganan risiko termasuk pilihan antara menangani risiko atau mengontrol risiko dengan tujuan untuk menurunkan dampak negatif tersebut. Penanganan risiko bertujuan untuk menghasilkan hasil yang positif dengan memilih prioritas dan aplikasi kombinasi dari penanganan risiko terbaik.

6) Monitor dan Review

Wahyudi (2013: 75) menyatakan bahwa tahapan review risiko, tingkat risiko aktual yang terjadi pada Bank Islam dimonitor dan dibandingkan dengan berbagai ketentuan risiko yang telah ditetapkan sebelumnya, seperti risk tolerance level, risk limit dan lain sebagainya. 


\section{Metode Penelitian}

Pendekatan penelitian yang dilakukan dalam penelitian ini adalah pendekatan kualitatif. Penelitian ini menggunakan strategi studi kasus. Menurut Yin (2015: 1) studi kasus merupakan strategi yang lebih cocok bila pokok pertanyaan suatu penelitian terkait dengan how atau why. Studi kasus merupakan suatu metode kajian empiris yang berusaha untuk menyelidiki fenomena yang terjadi di kehidupan nyata bilamana batas-batas antara fenomena kehidupan nyata dengan konteks tidak jelas dengan menggunakan berbagai sumber data. Alasan dari penggunaan studi kasus yaitu: (1) Hasil penelitian sulit untuk dimanipulasi karena penelitian ini hanya memiliki sedikit peluang untuk mengontrol peristiwaperistiwa yang akan diteliti, (2) Strategi menggunakan studi kasus sesuai dengan pertanyaan dalam penelitian ini yaitu "bagaimana", (3) Fokus pada penelitian ini yaitu tentang fenomena masa kini dalam konteks kehidupan nyata, yang dalam hal ini adalah mengenai manajemen risiko operasional BPRS Jabal Nur Sidoarjo. Berdasarkan hal tersebut, data yang diperlukan tidak cukup hanya data historis, melainkan diperlukan juga wawancara dan observasi di lapangan.

\section{Pembahasan}

Penetapan konteks manajemen risiko erat kaitannya dengan melakukan penetapan tujuan, strategi, ruang lingkup dan parameter-parameter lain yang berhubungan dengan proses pengelolaan risiko suatu perusahaan. Proses ini menunjukkan kaitan atau hubungan antara permasalahan hal yang akan dikelola risikonya dengan lingkungan perusahaan (eksternal \& internal), proses manajemen risiko, dan ukuran atau kriteria risiko yang hendak dijadikan standar. BPRS Jabal Nur Tebuireng menggunakan SOP dan SK Direksi dalam penentuan konteksnya. SOP dan SK direksi menjadi parameter atau batasan-batasan BPRS dalam kegiatan manajemen risikonya.

Penelitian ini dilakukan dengan tujuan untuk mengetahui penerapan manajemen risikiko operasional oleh PT BPRS Jabal Nur Tebuireng Surabaya. Subjek yang dipilih adalah Direktur dan Kepala Bagian Bisnis BPRS Jabal Nur Tebuireng dan beberapa karyawan sebagai informan.

\subsection{Analisis Tahapan Identifikasi dalam Manajemen Risiko Operasional di PT BPRS Jabal Nur Tebuireng Surabaya}

Proses manajemen risiko dibagi menjadi enam tahap, yaitu: (1) penentuan konteks, (2) identifikasi risiko, (3) analisis risiko, (4) evaluasi risiko, (5) perlakuan risiko, dan monitor serta review. Sedangkan cakupan risiko operasional sendiri, yang telah disebutkan pada bab 2 yaitu risiko manusia, risiko teknologi, risiko kepatuhan, risiko legal. Di BPRS Jabal Nur Tebuireng Surabaya, mengalami risiko risiko operasional, seperti yang dinyatakan oleh bu Puji selaku Direktur BPRS Jabal Nur Tebuireng dan didukung oleh karyawan-karyawan 
BPRS Jabal Nur Tebuireng yang lain. Berikut adalah rangkuman dari hasil analisis identifikasi risiko yang dilakukan BPRS Jabal Nur Tebuireng Surabaya.

Berdasarkan wawancara mengenai identifikasi risiko kepada keempat narasumber yaitu Bu Puji, Pak Jahid, Mas Adi dan Mbak Eni. Terdapat 13 risiko yang telah teridentifikasi pada PT BPRS Jabal Nur Tebuireng Surabaya. Dalam mengidentifikasi faktor risiko operasional, BPRS Jabal Nur Tebuireng Surabaya perlu memahami bagaimana risiko operasional diklasifikasikan. Risiko operasional dapat dibagi kedalam dua kelompok, yaitu risiko operasional berdasarkan faktor penyebab terjadinya dan berdasarkan frekuensi serta dampak terjadinya (Wahyudi, dkk, 2013:137).

Tabel 1.2

Hasil Analisis Identifikasi Risiko yang Dilakukan BPRS Jabal Nur Tebuireng Surabaya

\begin{tabular}{c|l}
\hline No. & \multicolumn{1}{|c}{ Macam-Macam Risiko } \\
\hline 1. & Kesalahan yang dilakukan teller dan Customer Service \\
\hline 2. & Karyawan bank melakukan fraud \\
\hline 3. & Kesalahan analisa dari marketing \\
\hline 4. & Jaringan PLN, Telkom, dan WIFI padam \\
\hline 5. & Nasabah melewati batas waktu pembayaran utang pembiayaan \\
\hline 6. & Kurangnya pengetahuan nasabah akan proses pelaksanaan akad \\
\hline 7. & Ketidak sesuaian perhitungan dengan persyaratan syariah \\
\hline 8 & $\begin{array}{l}\text { Panggilan Ke Pengadilan dikarenakan nasabah tidak terima asetnya } \\
\text { dijual }\end{array}$ \\
\hline 9. & Terdapat Uang Palsu \\
\hline 10. & Nasabah menggunakan jaminan yang bukan miliknya \\
\hline 11. & Nasabah mengajukan pembiayaan pada bisnis yang bukan miliknya \\
\hline 12. & Nasabah mengancam BPRS karena tidak terima utangnya di tagih \\
\hline 13. & Nilai jaminan yang tidak sesuai \\
\hline
\end{tabular}

\subsection{Analisis Tahapan Analisis Risiko dalam Manajemen Risiko Operasional di PT BPRS Jabal Nur Tebuireng Surabaya}

Berdasarkan data dilapangan ditemukan ada empat jenis risiko operasional yaitu atara lain adalah risiko manusia, risiko legal, risiko kepatuhan, dan risiko legal. Berikut akan dilakukan pengkodean atas uraian daftar risiko operasional PT BPRS Jabal Nur Tebuireng Surabaya. 
Tabel 1.3

Pengkodean Jenis Risiko Operasional PT BPRS Jabal Nur Tebuireng Surabaya

\begin{tabular}{|c|c|c|c|}
\hline No. & $\begin{array}{l}\text { Jenis } \\
\text { Risiko }\end{array}$ & Kode & Macam-Macam Risiko \\
\hline 1. & \multirow{7}{*}{$\begin{array}{l}\text { Risiko } \\
\text { Manusia }\end{array}$} & $1 \mathrm{a}$ & Kesalahan yang dilakukan teller dan Customer Service \\
\hline 2. & & $1 b$ & Karyawan bank melakukan fraud \\
\hline 3. & & $1 \mathrm{c}$ & Kesalahan analisa dari marketing \\
\hline 4. & & $1 d$ & Terdapat Uang Palsu \\
\hline 5. & & $1 \mathrm{e}$ & $\begin{array}{l}\text { Nasabah melewati batas waktu pembayaran utang } \\
\text { pembiayaan }\end{array}$ \\
\hline 6. & & 1f & Analisis nilai jaminan yang tidak sesuai \\
\hline 7. & & $1 \mathrm{~g}$ & $\begin{array}{l}\text { Nasabah mengancam BPRS karena tidak terima utangnya } \\
\text { di tagih }\end{array}$ \\
\hline 8 & \multirow{3}{*}{$\begin{array}{l}\text { Risiko } \\
\text { Legal }\end{array}$} & $2 \mathrm{a}$ & $\begin{array}{l}\text { Panggilan Ke Pengadilan dikarenakan nasabah tidak } \\
\text { terima asetnya dijual }\end{array}$ \\
\hline 9. & & $2 b$ & $\begin{array}{c}\text { Nasabah mengajukan pembiayaan pada bisnis yang bukan } \\
\text { miliknya }\end{array}$ \\
\hline 10. & & $2 \mathrm{c}$ & Nasabah menggunakan jaminan yang bukan miliknya \\
\hline 11. & \multirow{2}{*}{$\begin{array}{l}\text { Risiko } \\
\text { Kepatuhan }\end{array}$} & $3 a$ & $\begin{array}{c}\text { Kurangnya pengetahuan nasabah akan proses pelaksanaan } \\
\text { akad }\end{array}$ \\
\hline 12. & & $3 \mathrm{~b}$ & Ketidak sesuaian perhitungan dengan persyaratan syariah \\
\hline 13. & $\begin{array}{c}\text { Risiko } \\
\text { Teknologi }\end{array}$ & $4 \mathrm{a}$ & Jaringan PLN, Telkom, dan WIFI padam \\
\hline
\end{tabular}

Berikut hasil dari pengukuran daftar risiko dakaitkan dengan matriks penilaian risko. Pada tabel 1.4 telah diberi kode pada setiap kolom disesuaikan dengan peluang dan akibat yang ditimbulkan dari uraian risiko diatas:

Tabel 1.4

Matriks Pengukuran Risiko

\begin{tabular}{|c|c|c|c|c|c|}
\hline & \multicolumn{5}{|c|}{ Akibat/Dampak } \\
\hline \multirow[t]{2}{*}{ Peluang } & \multirow{2}{*}{$\begin{array}{c}1 \text { (Tidak } \\
\text { Siknifikan) }\end{array}$} & \multirow[b]{2}{*}{2 (Minor) } & \multirow{2}{*}{$\begin{array}{c}3 \\
\text { (Moderat) }\end{array}$} & \multirow[b]{2}{*}{4 (Major) } & \multirow{2}{*}{$\begin{array}{l}5 \text { (Sang at } \\
\text { Berbahaya } \\
\text { ) }\end{array}$} \\
\hline & & & & & \\
\hline \multicolumn{6}{|l|}{$\begin{array}{l}5 \text { (Hampir } \\
\text { pasti) }\end{array}$} \\
\hline \multicolumn{6}{|l|}{$\begin{array}{l}4 \\
\text { (Mungkin } \\
\text { Terjadi) }\end{array}$} \\
\hline 3 (Sedang) & $\begin{array}{l}1 \mathrm{a}, 3 \mathrm{a} \\
4 \mathrm{a}\end{array}$ & & & 1e & \\
\hline $\begin{array}{l}2 \text { (Kecil } \\
\text { Kemungki } \\
\text { nan) }\end{array}$ & & & 1c, & $\begin{array}{l}1 \mathrm{f}, 2 \mathrm{~b}, \\
2 \mathrm{c}\end{array}$ & $1 b$ \\
\hline $\begin{array}{l}1 \text { (Jarang } \\
\text { Sekali) }\end{array}$ & $1 d$ & $3 \mathbf{b}$ & $1 g, 2 a$ & & \\
\hline
\end{tabular}


Setelah dilakukan pengukuran mengenai risiko maka didapatkan yaitu rendah sebanyak 5 jenis uraian risiko operasional, level moderat sebanyak 3 jenis uraian risiko operasional, level signifikan terdiri dari 3 jenis uraian risiko operasional, dan level tinggi terdiri dari dua jenis uraian risiko operasional.

\subsection{Analisis Tahapan Evaluasi Risiko dan Perlakuan Resiko dalam Manajemen}

Berdasarkan pada informasi yang didapat dari hasil penelitian, BPRS melakukan tindakan terhadap risiko-risiko yang telah teridentifikasi, perlakuan risiko tersebut terdapat pada tabel 1.5 sebagai berikut:

Tabel 1.5

Hasil Analisis Perlakuan Risiko yang Dilakukan BPRS Jabal Nur Tebuireng Surabaya

\begin{tabular}{|c|c|c|}
\hline No. & Perlakuan Risiko & Cakupan Risiko \\
\hline 1. & $\begin{array}{l}\text { Rutin melakukan doa pagi dan memberi } \\
\text { dukungan kepada karyawan agar terhindar } \\
\text { dari perilaku menyimpang }\end{array}$ & Risiko ke \\
\hline 2. & Membatasi plafon pembiayaan & Risiko Manusia \\
\hline 3. & $\begin{array}{l}\text { Terus berkomunikasi dengan nasabah yang } \\
\text { macet dengan memberikan SP 1, SP 2, dan } \\
\text { SP } 3\end{array}$ & Risiko Manusia \\
\hline 4. & Memecat pegawai yang melakukan fraud & Risiko Manusia \\
\hline 5. & $\begin{array}{l}\text { Memberikan edukasi atau wawasan kepada } \\
\text { nasabah }\end{array}$ & Risiko Ma \\
\hline 6. & Memiliki alat sinar ultraviolet & Risiko Manusia \\
\hline 7. & Memiliki Genset & Risiko Teknologi \\
\hline 8. & Selalu komunikasi dengan DPS & Risiko Kepatuhan \\
\hline 9. & Menaikkan daya menjadi 6.600 & Risiko Teknologi \\
\hline 10. & $\begin{array}{l}\text { Menghadiri panggilan pengadilan tanpa } \\
\text { absen }\end{array}$ & Risiko Legal \\
\hline 12. & Menolak Nasabah dengan SID jelek & Risiko Manusia \\
\hline 13. & $\begin{array}{l}\text { Melakukan komunikasi ke Nasabah } \\
\text { mengenai perkembangan bisnisnya }\end{array}$ & Risiko Manusia \\
\hline 14. & $\begin{array}{l}\text { melakukan asuransi untuk produk } \\
\text { pembiayaan KPR }\end{array}$ & Risiko Manusia \\
\hline 15. & $\begin{array}{l}\text { Menggunakan metode analisis } 5 \mathrm{C} \text { untuk } \\
\text { nasabah yang akan dibiayai }\end{array}$ & Risiko Manusia \\
\hline 16. & Jaringan internet menggunakan kabel Optik & Risiko Teknologi \\
\hline
\end{tabular}

\section{Kesimpulan}


Berdasarkan pada hasil pembahasan yang telah dijelaskan, maka dapat disimpulkan bahwa manajemen risiko operasional yang dilakukan oleh BPRS Jabal Nur Tebuireng dilakukan dengan baik. Hal ini dapat dilihat dari manajemen risiko operasional yang dilakukan sesuai dengan proses manajemen risiko menurut ISO 31000, yakni sebagai berikut: (1) BPRS Jabal Nur Tebuireng Surabaya menentukan konteks risikonya dengan menggunakan SOP dan SK Direksi. (2) pada tahapan identifikasi risiko BPRS Jabal Nur Tebuireng Surabaya terdapat 13 risiko yang teridentifikasi. Risiko-risiko yang terjadi termasuk risiko yang baru terjadi dan telah terjadi di BPRS berasal dari internal maupun eksternal Bank dengan frekuensi dan dampak yang berbeda-beda. (3) tahapan Analisis risiko, BPRS Jabal Nur Tebuireng Surabaya tidak melakukan perhitungan composite risk index(CRI) dan matriks risiko, BPRS Jabal Nur Tebuireng hanya menggunakan analisis manual. (4) dalam tahapan manajemen resiko, BPRS Jabal Nur Tebuireng Surabaya melakukan evaluasi risiko oerasional maupun risiko lain. Evaluasi diadakan mingguan maupun bulanan dan dipimpin oleh Direksi. Sementara pada tahap perlakuan risiko diketahui bahwa 13 risiko yang telah diidentifikasi menggunakan strategi preventif dan mitigasi dalam menangani risikonya. Pada tahapan monitor dan review yang dilakukan BPRS Jabal Nur Tebuireng Surabaya adalah, selalu dibawah pengawasan DPS, dan dilakukannya internal audit.

\section{Daftar Pustaka}

Akbar, Fachri. 2016. Analisis Proses Manajemen Risiko Operasional di BNI Syariah KC Mikro Rungkut Surabaya. Surabaya: repository.unair.ac.id.

Ascarya. 2015. Akad Dan Produk Bank Syariah. Jakarta: PT Raja Grafindo Persada.

. ISO 31000:2009. Risk Management Principle and Guidelines. Sidney: Standard Australia.

Darmawi, Herman. 2008. Manajemen Risiko. Jakarta: Bumi Aksara.

Departemen Agama Republik Indonesia. 2013. Al Quran dan Terjemahannya. YPP/ Penafsir Al-Qur'an.

Ghassen Bouslamaa, dan Younes Lahrichi. Uncertainty and Risk Management from Islamic Perspective. (Online) (Research in International Business and Finance journal homepage: www.elsevier.com/locate/ribaf. Diakses November 2018)

Ghoffar, M 'Abdul. 2009. Tafsir Ibnu Katsir. Jakarta: Pustaka Imam Asy-Syafi'i.

Greuning, Hennie Van dan Zamir Iqbal. 2011. Analisis Risiko Perbankan Syariah. Jakarta: Salemba Empat.

Hendrawan, Reza Waskito. 2011. Manajemen Risiko Pembiayaan PrinsipBagi Hasil pada Bank Pembiayaan Rakyat Syariah (Study Kasus pada BPRS Madinah Lamongan. Surabaya: repository.unair.ac.id.

Huda, Nurul. 2010. Lembaga Keuangan Islam Tinjauan Teoritis dan Praktis. Jakarta: Kencana 
Idroes, Ferry N. 2008. Manajemen Risiko Perbankan: Pemahaman Pendekatan \# Pilar Kesepakatan Basel II Terkait Aplikasi Regulasi dan Pelaksanaannya di Insonesia. Jakarta: PT Raja Grafindo Persada.

Ikatan Bankir Indonesia. 2014. Memahami Bisnis Bank Syariah. Jakarta: PT Gramedia Pustaka Utama

Mardani. Fiqh Ekonomi Syariah. 2012. Jakarta: Kencana.

Muhammad. 2011. Manajemen Bank Syari'ah. Yogyakarta: UPP STIM YKPN

Otoritas Jasa Keuangan. 2015. Buku Saku Otoritas Jasa Keuangan. (Online) (www.ojk.go.id. Diakses September 2017)

Otoritas Jasa Keuangan. 2016. Industri Jasa Keuangan. (Online) (www.ojk.go.id. Diakses September 2017)

Pradipta, Arya. 2016. Strategi Manajemen Risiko Pembiayaan UMKM pada Program BNI Syariah Mikro (studi kasus pada BNI Syariah cabang Mikro Rungkut Surabaya. Surabaya: repository.unair.ac.id.

Puspitho, Pratiwi. 2013. Manajemen Risiko dalam Perbankan Syariah Di Indonesia.Jember: repository.unej.ac.id

Republik Indonesia. 2003. Peraturan Bank Indonesia Nomor 5 Tahun 2003 Tentang Penerapan Manajemen Risiko Bagi Bank Umum. (Online) (www.bi.go.id. Diakses September 2017)

Republik Indonesia. 2011. Peraturan Bank Indonesia Nomor 13/23/2011 Tentang Penerapan Manajemen Risiko Bank Umum Syariah dan Unit Usaha Syariah. (Online) (www.bi.go.id. Diakses September 2017

Sudarsono, Heri. 2007. Bank Dan Lembaga Keuangan Syariah Deskripsi dan Ilustrasi Edisi2. Yogyakarta: Ekonisia.

Sugiyono.2010. Metode Penelitian Pendidikan. Bandung: Alfabeta.

Suhendi M.SI, Hendi. 2016. Fiqh Muamalah. Jakarta: PT Raja Grafindo Persada.

Wahyudi, Imam dkk. 2013. Manajemen Risiko Bank Islam. Jakarta: Salemba Empat.

Yin, K. Robert. 2009. Studi Kasus: Desain \& metode. Jakarta: Raja Wali.

Yin, K. Robert. 2015. Studi Kasus: Desain \& Metode. Jakarta: PT Raja Grafindo Persada.

www.bi.go.id. Diakses pada Februari 2018

www.ojk.go.id. Diakses pada September 2017. 